\title{
Air pollution assessment in urban environment of Krasnoyarsk city
}

\author{
Ekaterina N. Bel'skaia ${ }^{1}$, Olga V. Taseiko ${ }^{1,2}$ and Alexey V. Kotov ${ }^{1}$ \\ ${ }^{1}$ Reshetnev Siberian State University of Science and Technology, Krasnoyarsk, Russia \\ ${ }^{2}$ Federal Research Center for Information and Computational Technologies, Krasnoyarsk, Russia
}

\begin{abstract}
In this paper an assessment of air pollution in Krasnoyarsk for 2017-2019 is carried out based on the observations primary data of stationary posts for monitoring the state of air quality; the location of the posts with an indication of the development type is shown.
\end{abstract}

\section{Keywords}

Urban air pollution, observation data, type of building.

\section{Introduction}

Krasnoyarsk is one of the largest cultural, educational and industrially developed cities in Russia. The air pollution problem of the urban environment by emissions from various activities is very acute. Location of large energy facilities, chemical and metallurgical enterprises in the city; autonomous sources of heat supply; non-compliance of vehicles with environmental requirements; constant increase in the fleet of cars; low street capacity; the state of the dust and gas cleaning equipment at the industrial enterprises of the city, which requires modernization [1]; the lack of green space are factors contributing to the deterioration in the ecological state of the city.

The pollutants selected for the assessment are included in the list of priority chemical compounds of non-carcinogenic action, when studying the impact of the environment on human health. Carbon monoxide (CO) is a substance of the $4^{\text {th }}$ hazard class, often used in assessing air quality due to its chemical inertia; the annual air quality standard $\left(\mathrm{AQS}_{\mathrm{a}}\right)$ is equal $3 \mathrm{mg} / \mathrm{m}^{3}$; diseases of the cardiovascular and central nervous systems, the hematopoietic system. Nitrogen dioxide $\left(\mathrm{NO}_{2}\right)$ is a substance of the $3^{\text {rd }}$ hazard class, characterized by high toxicity, has high chemical activity, one of the most common air pollutants today which plays a significant role in the formation of smog and acid precipitation; the average annual maximum permissible concentration of $\mathrm{AQS}_{\mathrm{a}}=0.04 \mathrm{mg} / \mathrm{m}^{3}$; groups of diseases are respiratory diseases, changes in blood composition, possible oxygen starvation of tissues.

SDM-2021: All-Russian conference, August 24-27, 2021, Novosibirsk, Russia $\bigoplus$ ketrin_nii@mail.ru (E.N. Bel'skaia); taseiko@gmail.com (O.V. Taseiko)

(c) (1) ๑ 2021 Copyright for this paper by its authors. Use permitted under Creative Commons License Attribution 4.0 International (CC BY 4.0).

$[\mathrm{m}=\mathrm{m}$ 


\section{Research methods and materials}

The paper is based on the primary data of the air quality monitoring network provided by the "Central Siberian Administration for Hydrometeorology and Environmental Monitoring" (Central Siberian AHEM) [2] and the Regional State Budgetary Institution "Center for the implementation of strategy for the environmental using and protection of the Krasnoyarsk region" (CEUP) [3] (Figure 1) using the methods of mathematical statistics, an assessment of the air pollution in Krasnoyarsk in terms of $\mathrm{CO}$ and $\mathrm{NO}_{2}$ for the period 2017-2019 was carried out. The relationship between the levels of pollution and the time dynamics of pollutants with the characteristics of the development is analyzed.

\section{Results and discussion}

There are two networks on the Krasnoyarsk territory for monitoring the air quality the federal one, represented by the posts of the Central Siberian AHEM and the regional one implemented by CEUP. Despite the fact that the total number of air pollution monitoring stations has increased the variety of conditions that they characterize has changed slightly. When modeling the process of dispersion of pollutants in the atmosphere of a city, the factors that shape these processes are important such as the width of highways and the average height of adjacent buildings and the density of buildings. Table 1 shows the location of the posts indicating the area, address, height of nearby buildings, width of highways and type of development.

According to the observations results of the Central Siberian AHEM and CEUP for the review period in 2017-2019 the average annual concentrations, according to [4, 5]: for CO did not exceed the established average annual $\mathrm{AQS}_{\mathrm{a}}$ - Figure 2; the excess for $\mathrm{NO}_{2}$ was (1.1 and $1.7 \mathrm{AQS}_{\mathrm{a}}$, respectively) - Figure 3.

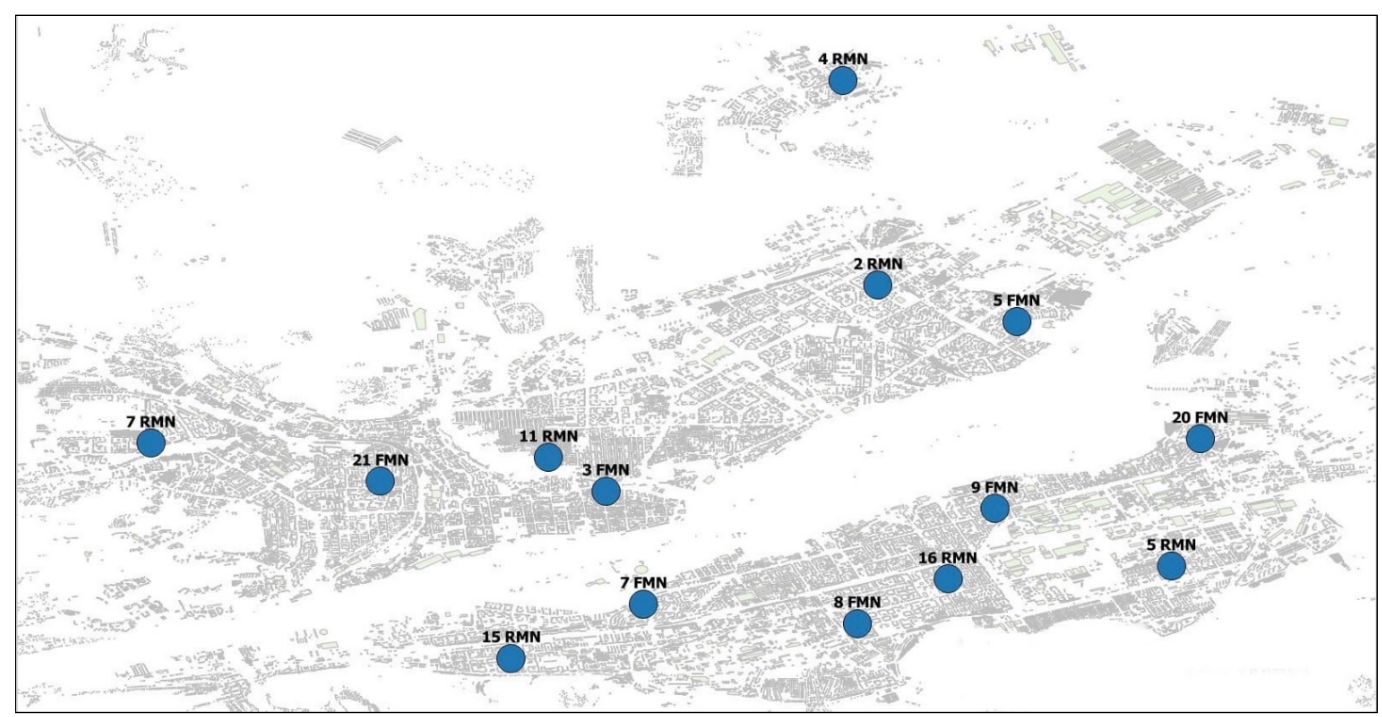

Figure 1: Location of observation posts of Central Siberian AHEM and CEUP (Regional and Federal monitoring network). 
Table 1

Location of observation posts

\begin{tabular}{|c|c|c|c|c|c|c|}
\hline $\begin{array}{l}\text { Moni- } \\
\text { toring } \\
\text { system }\end{array}$ & $\begin{array}{c}\text { Post } \\
\text { no }\end{array}$ & $\begin{array}{l}\text { Location } \\
\text { area }\end{array}$ & Address & $\begin{array}{c}\text { Type } \\
\text { of } \\
\text { building }\end{array}$ & $\begin{array}{l}\text { Highway } \\
\text { width, m }\end{array}$ & $\begin{array}{c}\text { Height of } \\
\text { buildings, } \\
\text { m }\end{array}$ \\
\hline \multirow{8}{*}{ 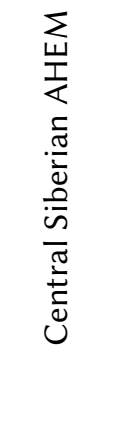 } & 1 & Oktyabrsky & 14d Minusinskaya str. & II & 2 & 1 \\
\hline & 3 & Central & 54 m Surikov str. & $\mathrm{I}$ & 5 & 4 \\
\hline & 5 & Soviet & 4d Bykovsky str. & III & 24. & 5 \\
\hline & 7 & Sverdlovsk & 6d A. Matrosov str. & IV & 10 & 5 \\
\hline & 8 & Kirovsky & 92g Kutuzov str. & I & $10.5(16)$ & 5 \\
\hline & 9 & Leninsky & 7d Chaikovsky str. & VI & $10(16)$ & 9 \\
\hline & 20 & Leninsky & $\begin{array}{l}\text { 26d } 26 \text { Baku } \\
\text { Commissars str. }\end{array}$ & III & 9.6 & 9 \\
\hline & 21 & Railway & $\begin{array}{l}\text { 32d Krasnomos- } \\
\text { kovskaya str. }\end{array}$ & I & 12 & 16 \\
\hline \multirow{7}{*}{ 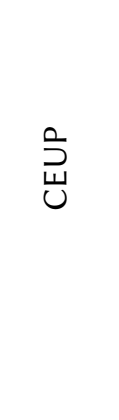 } & 2 & Northern & $\begin{array}{l}\text { Mate Zalki str., } \\
\text { between } 4 \text { and } 4 a\end{array}$ & IV & 10.7 & 9 \\
\hline & 4 & Sunny & 2 Sunny Boulevard & III & 9 & 4 \\
\hline & 5 & Cheryomushki & 50 Lvovskaya str. & V & 8.8 & 5 \\
\hline & 7 & Vetluzhanka & $\begin{array}{c}\text { Gusarova str., } \\
\text { between 1a and } 9\end{array}$ & V & 9 & $10(5)$ \\
\hline & 11 & Pokrovka & 86 Aviatsionnaya str. & II & 8 & 1 \\
\hline & 15 & Sverdlovsk & 4660 let Oktyabrya str. & $\mathrm{V}$ & 3 & 4 \\
\hline & 16 & Kirovsky & $\begin{array}{c}\text { 21/1 Akademika } \\
\text { Pavlova str. }\end{array}$ & V & $8(12)$ & 9 \\
\hline
\end{tabular}
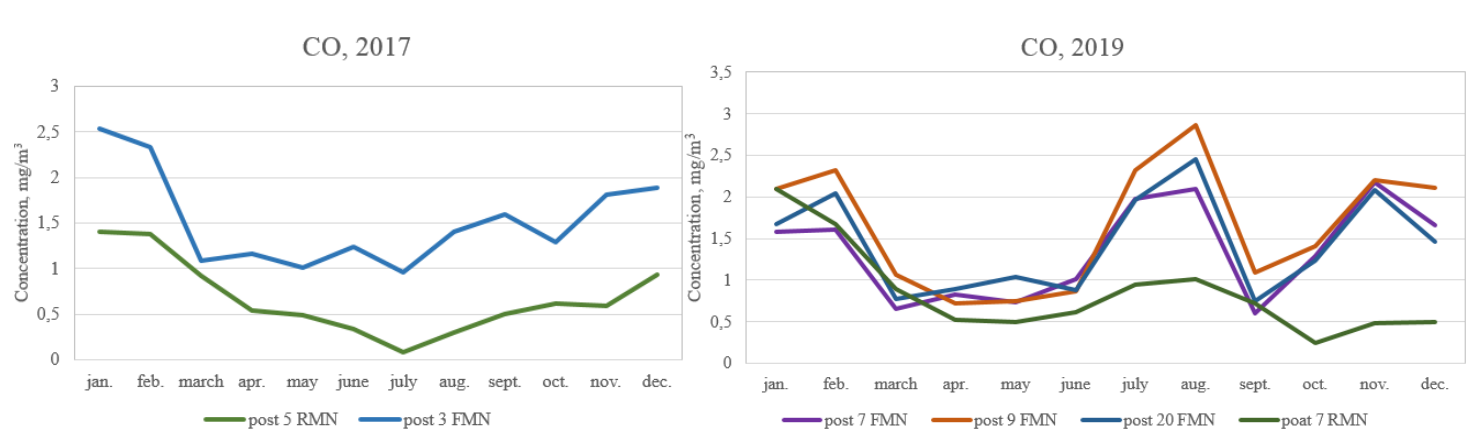

Figure 2: CO concentrations for 2017, 2019, Central Siberian AHEM and CEUP (Regional and Federal monitoring network), the line shows the level of $\mathrm{AQS}_{\mathrm{a}}$.

The dispersion of vehicular and enterprise's emissions in urban areas is defined by the wind flow interaction with individual buildings, streets and trees. The flow direction and velocity are a result of the interaction between the outer flow and the type and arrangement of buildings in their surroundings. To accurately simulate pollution concentrations in built-up areas we need detailed information about the height and width of the buildings, their configuration, the spacing between them, street widths, etc. Each type of building has its own aerodynamic properties 

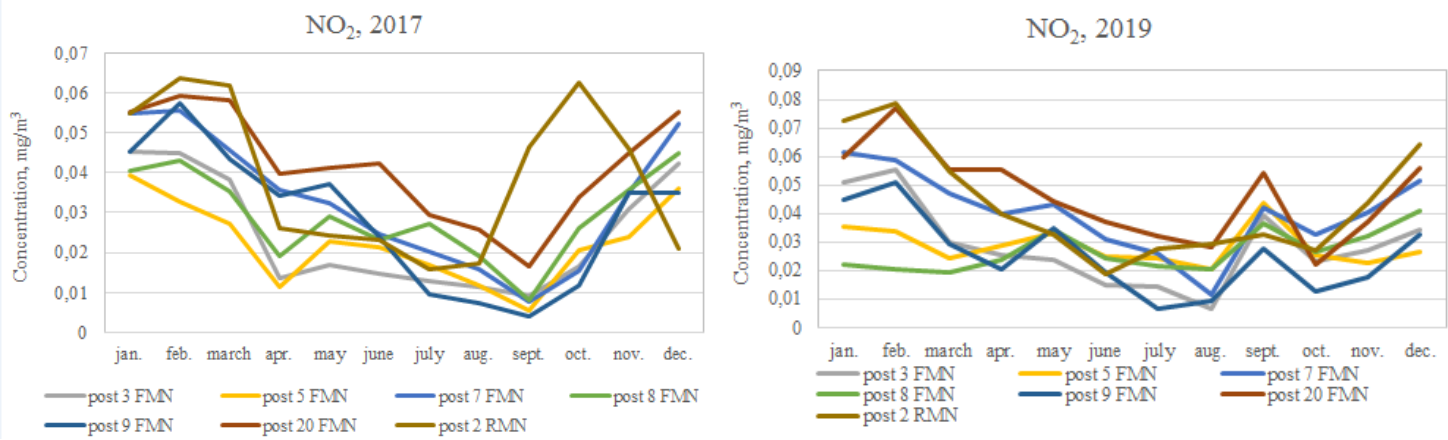

Figure 3: $\mathrm{NO}_{2}$ concentrations for 2017, 2019, Central Siberian AHEM and CEUP (Regional and Federal monitoring network), the line shows the level of $A Q S_{a}$.

and individual characteristics of the microclimate. The wind flow around the buildings forms complex closed circulation zones. The nature and size of these zones depend on the geometric shape and size of buildings and the density of buildings and can form stable vortices that prevent the dispersion of harmful substances. Therefore the layout of city blocks, the density of buildings their size and height should be taken into account when modeling dispersion conditions. To describe the horizontal structure of built-up areas, the symmetry of the buildings location was studied. Typical layouts of urban development in Krasnoyarsk can have an isotropic type and a building with the symmetry axes of the second and fourth orders located at an angle of 1800 and 900 respectively. The isotropic type characterizes irregular building structures that do not have a dedicated direction of horizontal wind flow. In isotropic regions the advective properties do not depend on the wind direction. Two parameters were used to classify the types of building structures: the axis of symmetry and the average height of the buildings. Taking into account these parameters six main types of urban planning configurations of Krasnoyarsk are identified which are also typical for many cities in Russia and Siberia (Table 2).

Table 2

Type of building arrangements in Krasnoyarsk city

\begin{tabular}{|c|c|c|c|c|c|c|}
\hline $\begin{array}{l}\text { Type of } \\
\text { building }\end{array}$ & 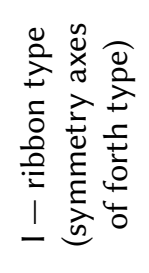 & 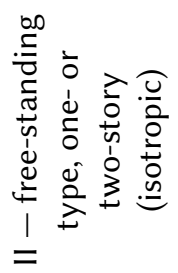 & 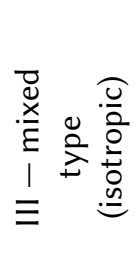 & 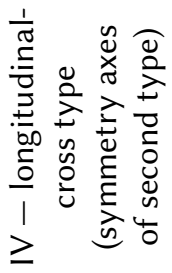 & 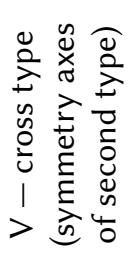 & 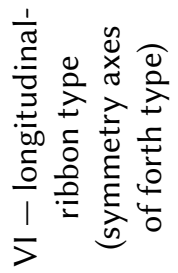 \\
\hline $\begin{array}{l}\text { Types of } \\
\text { building } \\
\text { arrange- } \\
\text { ment }\end{array}$ & 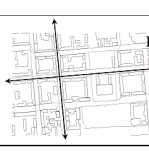 & & & & 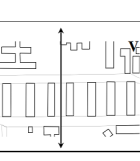 & \\
\hline $\begin{array}{l}\text { Occupied } \\
\text { territory, } \%\end{array}$ & 35 & 20 & 10 & 2 & 3 & 30 \\
\hline
\end{tabular}


The state of air quality in Krasnoyarsk city is characterized by exceeding the permissible levels for many pollutants, including nitrogen dioxide which undoubtedly negatively affects the living conditions and the health of the population. Figure 3 shows the average annual $\mathrm{NO}_{2}$ concentrations for 2017 and 2019. Exceeding the maximum permissible concentrations is obvious in winter concentrations increase at all observation posts, regardless of the development type. However minimum values are observed for types III (isotropic) and IV (longitudinal-transverse). When analyzing the maximum values of $\mathrm{NO}_{2}$ concentrations, type III of building (isotropic) is also observed.

The analysis of the CO concentration's extremes showed the minimum values for the type V (transverse) type, the maximum values for the types I (perimeter) and IV (longitudinaltransverse).

The horizontal component of the wind speed is constant in isotropic building structures. The area with the symmetry axis of the second type is characterized by the maximum value of the horizontal wind speed on one axis (one axis - two opposite directions) and the area with the symmetry axis of the fourth type is characterized by the maximum value of the horizontal wind speed on two axes (two perpendicular axes - four directions). Each type can be found in different parts of the city, characterized by different building densities (defined as the ratio between the sum of the area for buildings located in the area and the size of this area) and functional types [6].

The density of buildings with the symmetry axis of the $4^{\text {th }}$ order (type I) with a height of about $15 \mathrm{~m}$ is about $30-40 \%$. Type II is characterized by a building density of about $15-25 \%$, and these buildings are mostly single-storey (about 3-5 m high). Type III has tall buildings (about $40 \mathrm{~m}$ ) and a building density of about 30-65\%. Type IV has a low building density (10-20\%) with a height of $15 \mathrm{~m}$. In type $\mathrm{V}$ the height of the buildings is about $40 \mathrm{~m}$ but their density is about $20-30 \%$. Type VI is mixed and combines the characteristics of types I and V. The density of this building type is lower than that of type I (15-25\%). Type VI has buildings of the ribbon-longitudinal type and the average height of the buildings is about $30 \mathrm{~m}$.

The greatest accumulation of pollutants in the urban air is observed in the type III of building, which is due to the lack of blowing capacity for blocks of this design. Here, the height of the buildings and the density of their location will play an important role. The direction of the undisturbed wind flow running into the city will play an important role for the blowing capacity of the IV and V buildings types. Types I and VI of buildings most effectively contribute to the purification of the air. But with a wind speed above $15 \mathrm{~m} / \mathrm{s}$ all these differences will not be significant since such a wind flow will purify the air from all types of pollution both gaseous substances and solid particles.

Currently, there is no comprehensive, accurate representation of the multiple factors influencing urban wind flows and therefore urban air quality. Wind tunnel experiments do not completely show real physical processes and mathematical modeling presents a simplified version of these processes. Therefore, only in-situ observations and measurements can give researchers the data they need to understand the transformations of urban wind flows [7]. However, the detailed monitoring of an entire city requires complete, accurate measurements taken over many years, which is expensive. Actual urban monitoring is usually done for quite limited areas and periods of time. These results improve the understanding of the processes of urban wind flow transformation which can be used for many purposes, including city planning 
and management. It can be used to verify of numerical simulation models for air pollution dispersion and to further use this information to better parametrize a wide range of problems of wind flows in urban areas.

Underestimating the levels of urban air pollution by harmful substances can lead to an increase in the number of pathological conditions associated with their exposure. The air quality standards used in our country are not always justified by the effects directly related to health [8]: $30 \%$ of the AQS in populated areas is established by human reflex reactions. The level of air pollution in the city with the existing emissions volume of harmful substances is determined in addition to local scattering factors of individual territories also by meteorological conditions. The main weather parameters in the city conditions include: wind speed and direction, characteristics of inversions, stagnant situations.

The complexity in solving the problem of managing the ecological state of the city is due to the existing approach as a secondary one, despite its obvious relevance. Methods for implementing air quality management systems are declared by law but the organizational management mechanism and the regulatory documents that support it are not fully developed [1] which certainly hinders the implementation of measures to reduce emissions of pollutants into the city's atmosphere. Of course, further violations detection of the current sanitary and hygienic standards is necessary and even their revision is necessary [8] which is caused on the one hand by the lack of connection between the current AQS and the health of the population on the other hand by the general inefficiency of the environmental quality management system.

\section{Acknowledgments}

This research project No 18-47-240006: "Methods and information technologies for risk assessment of the development of socio-natural-technogenic systems in an industrial region" was funded by the Russian Foundation for Basic Research, Government of Krasnoyarsk Territory, Krasnoyarsk Regional Fund of Science.

\section{References}

[1] Novikova S.A. Atmospheric air pollution in large cities of the Krasnoyarsk Territory // Russia’s National Priorities, 2019. No. 2(33). URL: https://cyberleninka.ru/article/n/ zagryaznenie-atmosfernogo-vozduha-krupnyh-gorodov-krasnoyarskogo-kraya/viewer.

[2] Federal State Budgetary Institution "Central Siberian Administration for Hydrometeorology and Environmental Monitoring”. Observation network. URL: http://meteo.krasnoyarsk.ru/ФГБУСреднесибирскоеУГМС/Наблюдательнаясеть/tabid/ 221/Default.aspx.

[3] Regional State Budgetary Institution "Center for the Implementation of Measures for the Use of Natural Resources and Environmental Protection of the Krasnoyarsk Territory". URL: http://krasecology.ru/Air/ChangesReview.

[4] Sanitary rules and norms 1.2.3685-21 "Hygienic standards and requirements for ensuring the safety and (or) harmlessness of environmental factors for humans". Utv. Resolution No. 2 of the Chief Sanitary Doctor of the Russian Federation of 28.01.2021. 
[5] State report on the state of the environment in the Krasnoyarsk Territory in 2019. URL: http://www.mpr.krskstate.ru/dat/bin/art/45884_svodnij_doklad_2019.pdf.

[6] Taseiko O.V., Mikhailuta S.V., Pitt A. et al. Air pollution dispersion within urban street canyons // Atmospheric Environment. 2009. Vol. 43. No. 2. P. 245-252. DOI:10.1016/j.atmosenv.2008.09.076.

[7] Mikhailuta S.V., Taseiko O.V., Lezhenin A.A., Pitt A. Urban wind fields: Phenomena in transformation // Urban Climate. 2017. Vol. 19. P. 122-140. DOI:10.1016/j.uclim.2016.12.005.

[8] Shokin Yu.I., Moskvichev V.V., Taseiko O.V., Bel'skaia E.N. Definition of environmental quality standards based on a risk-based approach // Bulletin of the Russian Academy of Sciences. 2020. Vol. 90. No. 12. P. 53-63. 